\title{
Calanoid copepod grazing affects plankton size structure and composition in a deep, large lake
}

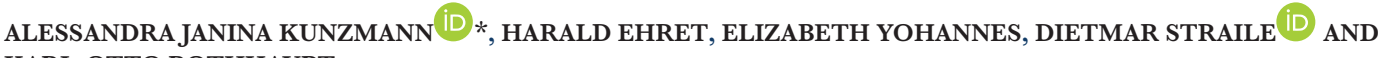 \\ KARL-OTTO ROTHHAUPT \\ LIMNOLOGIGAL INSTITUTE, UNIVERSITY OF KONSTANZ, MAINAUSTRAßE 252, 78457 KONSTANZ, GERMANY \\ *CORRESPONDING AUTHOR: alessandra.kunzmann@uni-konstanz.de
}

Cultural oligotrophication is expected to shift lake zooplankton to become dominated by calanoid copepods. Hence, understanding the influence of calanoids on the taxonomic and size structure of the lower plankton food web is crucial for predicting the effects of oligotrophication on energy fluxes in these systems. We studied the effect of an omnivorous calanoid, Eudiaptomus gracilis, on the lower planktonic food web using an in situ incubation approach in large and deep Lake Constance. We show that E. gracilis significantly reduced ciliate, phytoplankton, rotifer, but increased bacteria biovolume. Highest clearance rates were observed for ciliates whose biovolume declines may have caused a release of predation pressure on bacteria. E. gracilis grazing shifted the size structure of the phytoplankton community by reducing mean phytoplankton cell size (directional selection) and simultaneously increasing cell size variance (disruptive selection). Ciliate cell sizes experienced a similar selective regime in one of the experiments, whereas in the other two experiments, no change of size structure was detected. Results suggest strong influences of E. gracilis grazing on the lower plankton food web and a significant shift in phytoplankton size structure. For evaluating detailed effects of omnivorous consumers on plankton size structure, cascading interactions need to be considered.

KEYWORDS: directional and disruptive selection; omnivory; food web interactions; community structure; cascading interactions 


\section{INTRODUGTION}

Body size is considered as a master trait in planktonic food webs because it is correlated with many physiological and life-history traits of organisms (Litchman et al., 2007; Gianuca et al., 2016). Body size controls growth, nutrient uptake and sedimentation as well as the vulnerability of organisms to predation (Sommer et al., 2017). Hence, it is a key factor for energy transfer and nutrient regeneration within ecosystems (Hildrew et al., 2007; Arhonditsis et al., 2018).

In aquatic habitats, predator-prey relationships have been shown to be highly size-dependent (Hansen et al., 1994; Scharf et al., 2000; Emmerson and Raffaelli, 2004; Folke et al., 2004). Usually, consumers prefer specific cell or body sizes of prey organisms resulting in predator-prey body size ratios based on the predator's feeding behaviour, e.g. foraging tactics, mode of ingestion or food preferences (Hansen et al., 1994, 1997; Brose et al., 2006). Amongst other factors, size-specific predation might play an important role for seasonal plankton succession (DeMott, 1989; Gliwicz and Pijanowska, 1989).

Numerous lakes in Europe and Northern America are currently undergoing oligotrophication, resulting in changes in the composition of planktonic food webs. (Søndergaard et al., 1990; Jeppesen et al., 2002, 2005; Van Donk et al., 2008; Bunnell et al., 2014; Watkins et al., 2015). Copepods are key components within these food webs and calanoid copepods in particular dominate the crustacean zooplankton biomass in oligotrophic waters (Straile and Geller, 1998). Consequently, the relative importance of calanoid copepods is likely to increase in lakes which currently experience declines in nutrients, i.e. (re-) oligotrophication (Barbiero et al., 2012, 2014; Rudstam et al., 2015; Straile, 2015).

Calanoid copepods are known to switch their feeding mode from passive suspension feeding to ambush feeding depending on the concentration of prey (Vanderploeg and Paffenhöfer, 1985). This allows calanoid species to feed on a broad size range and high diversity of prey organisms (Stoecker and Egloff, 1987; Carrick et al., 1991; Fessenden and Cowles, 1994; Adrian and Schneider-Olt, 1999; Šorf and Brandl, 2012). Several studies indicate size- and taxon-specific ingestion by small calanoid copepods. For instance, small calanoids similar in size to Eudiaptomus gracilis (e.g. Boeckella spp., Diaptomus minutus, Diaptomus pygmaeus, Epischura baikalensis, Epischura lacustris, Eudiaptomus graciloides) have been shown to highly select for ciliates with preference for smaller ciliates (size range: $10-20 \mu \mathrm{m})$ over smaller-sized algae $(\leq 10 \mu \mathrm{m})$ as well as large ciliates (>20 $\mu \mathrm{m})$ (Burns and Gilbert, 1993; Burns and Schallenberg, 1996; Burns and Schallenberg, 1998; Adrian and Schneider-Olt, 1999; Burns and
Schallenberg, 2001). Less is known about small calanoid predation effects on rotifers (Williamson and Butler, 1986; Dhanker et al., 2012). In contrast, large calanoids (Calanus propinquus, D. pallidus, E. lacustris, E. nevadensis, Limnocalanus macrurus) feed primarily on larger animal prey such as rotifers and small crustaceans in addition to phytoplankton (Warren, 1985; Wong and Chow-Fraser, 1985; Schulze and Folt, 1990; Pasternak and SchnackSchiel, 2001; Doubek and Lehman, 2014). Thus, both predator and prey sizes control the selective feeding behaviour of calanoids and therefore the structure of the prey community.

In many deep, peri-alpine European lakes, the calanoid copepod Eudiaptomus gracilis is abundant throughout the year (e.g. Anneville et al., 2007; Seebens et al., 2007). E. gracilis was long considered as a herbivorous species and therefore, many experimental studies were performed using algal dietary sources (Muck and Lampert, 1980; Horn, 1985a, b). Amongst phytoplankton, E. gracilis predominantly feeds on larger species and hence has been termed a 'macro-filtrator' (Horn, 1985a, b). However, E. gracilis also feeds on small algae groups such as Scenedesmus $\left(\sim 200 \mu \mathrm{m}^{3}\right)$ with enhanced filtering rates (Muck and Lampert, 1980). More recently, there is evidence for carnivorous feeding with studies showing preference for ciliates (Adrian and Schneider-Olt, 1999; Yoshida et al., 2001) and rotifers up to $260 \mu \mathrm{m}$ in body length and a body volume of $340000 \mu \mathrm{m}^{3}$, respectively (Brandl, 2005; Šorf and Brandl, 2012). Thus, E. gracilis seems to be an omnivorous consumer able to prey on primary producers (phytoplankton) but also on primary consumers (herbivorous ciliates and rotifers) and secondary consumers, e.g. predatory ciliates (Müller et al., 1991). This suggests the potential for complex and cascading effects of this copepod's feeding on the structure and size of plankton communities.

Recently, Vellend proposed his 'theory of ecological communities' in which he advocated to organize community ecology into four high-level processes in analogy to evolutionary biology (natural selection theory): drift, selection, dispersal and speciation (Vellend, 2010, 2016). Using this framework, the grazing impact of a herbivore on a multispecies community may be conceptualized as selection of species resulting in changes in species and trait composition within a community. Accordingly, directional selection will change the mean of the prey size frequency distribution inducing a shift towards one end of the size spectrum; stabilising selection will decrease the variance of the size frequency distribution, whereas disruptive selection will increase the variance of the size frequency distribution (Coutinho et al., 2016).

In this study, we analyse the direct and indirect influence of one of Europe's most common calanoid copepods, E. gracilis, on a natural plankton community 
(rotifers, ciliates, heterotrophic flagellates, phytoplankton and bacteria) using an experimental approach in Lake Constance. We assess the impact of E. gracilis on the size structure and composition of the lower plankton food web during autumn as long-term data from this lake indicated that the copepod's abundance increases during this season (Seebens et al., 2007).

More specifically, we test the following four hypotheses:

1) The grazing impact of E. gracilis is prey-size dependent resulting in largest clearance rates for rotifers, followed by ciliates and phytoplankton,

2) Grazing of E. gracilis results in cascading trophic interactions, i.e. high clearance rates for ciliates (large prey) will release bacteria (small prey) from predation,

3) Size-selective copepod feeding within taxonomic prey groups (phytoplankton, ciliates and rotifers) will result in smaller average body sizes (directional selection) and reduced body size variances (stabilising selection) within those groups, and

4) The effect of E. gracilis on the biovolume and the mean and variance of body size of plankton groups does show short-term (within weeks) temporal variation.

\section{METHOD}

\section{Study system}

To examine the grazing impact of E. gracilis and its shortterm variability, we conducted three bottle experiments during a 3-week period in autumn 1998 in Überlinger See, a fjord-like basin of Upper Lake Constance $\left(47^{\circ}\right.$ $\left.45^{\prime} \mathrm{N}, 9^{\circ} 08^{\prime} \mathrm{E}\right)$. Briefly, Upper Lake Constance is a large $\left(473 \mathrm{~km}^{2}\right)$, deep (maximum depth: $252 \mathrm{~m}$ ), warm-monomictic peri-alpine lake bordering Germany, Switzerland and Austria, which experienced reoligotrophication during the last decades (Jochimsen et al., 2013). During the study year, the lake was mesotrophic with a total phosphorus concentration of $0.55 \mu \mathrm{mol} \mathrm{P} \mathrm{L} \mathrm{L}^{-1}$ in September.

\section{Incubation experiments}

On the day before each of the three experiments (Experiment 1: 21 September; Experiment 2: 28 September and Experiment 3: 05 October 1998), specimens of $E$. gracilis were collected with a HYDROBIOS plankton net (38.5 $\mathrm{cm}$ diameter, $55 \mu \mathrm{m}$ mesh size) in four vertical tows from 0 to $25 \mathrm{~m}$ depth and kept overnight in filtered lake water $(0.45 \mu \mathrm{m}$ pore size $)$ at $17.2^{\circ} \mathrm{C}$. Most of the copepods were adult egg-sac bearing females. Environmental conditions during the overall study period where rather stable with Secchi depths slightly increasing from 5.8 (Experiment 1) to $7.4 \mathrm{~m}$ (Experiment 2), and $8.4 \mathrm{~m}$ (Experiment 3) and epilimnetic water temperatures (measured in $2 \mathrm{~m}$ depth) varying $\sim 14^{\circ} \mathrm{C}$ (Experiment 1: $14^{\circ} \mathrm{C}$, Experiment 2: $14.7^{\circ} \mathrm{C}$ and Experiment 3: $13.8^{\circ} \mathrm{C}$ ).

On the first day of each experiment, eight transparent PVC bottles of $\sim 1250 \mathrm{~mL}$ volume were filled in situ with lake water from a depth-integrated sample (0-20 m) gently mixed and filtered through a $55 \mu \mathrm{m}$ mesh (Experiment 3: $100 \mu \mathrm{m})$ to remove mesozooplankton. Samples from the filtered lake water were directly taken as duplicates to define the initial microplankton composition $(\mathrm{S})$ at the starting point of the study. Subsequently, four bottles (E1E4) were populated with 30 adult individuals of E. gracilis individually, the remaining four bottles without copepods served as control/no copepod treatment (C1-C4). Similar densities of $E$. gracilis were reported for natural lake habitats, e.g. up to 22 ind $\mathrm{L}^{-1}$ in Lake Balaton (Zánkai and Ponyi, 1986) and up to 9 ind $\mathrm{L}^{-1}$ in Lake Constance (Stich, 1989). Also, the chosen copepod density lay within the density ranges used in previous mesocosm studies and was likely to trigger trophic cascading effects (Adrian and Schneider-Olt, 1999; Sommer et al., 2001; Sommer et al., 2004; Zöllner et al., 2009). All bottles were incubated in $2 \mathrm{~m}$ water depth for $72 \mathrm{~h}$ to allow the microbial community to respond to multi-level grazing whilst minimising enclosure effects, e.g. algal growth on enclosure walls (c.f. Burns and Schallenberg, 1996). Also, in $2 \mathrm{~m}$ depth, the bottles were affected by wind driven water movement, which generated turbulence and reduced sedimentation of immobile plankton. The total exposure time until plankton fixation amounted to $74 \mathrm{~h}$.

\section{Plankton cell concentrations and biomass}

To quantify changes in pico- and microplankton due to feeding of E. gracilis, we estimated the abundances (cells $/ \mathrm{mL}$ ) of the different plankton groups in the control (C) and Eudiaptomus (E) bottles at the end of each experiment. In addition, plankton densities at the start of each experiment (S), i.e. from the water used to fill the experimental bottles, were examined and used as a reference to illustrate temporal dynamics in both control and predator treatment. After fixation in Lugol's acid solution + sodium acetate $(100 \mathrm{~mL}$ sample volume per replicate), phytoplankton species were counted following Utermöhl (1958). Individual samples $(250 \mathrm{~mL}$ sample volume per replicate) of both ciliates and rotifers were fixed in Lugol's acid solution $+10 \%$ glacial ethanoic acid and counted as combined samples. Subsamples of $100 \mathrm{~mL}$ were counted until 200 individuals of the most common taxon were obtained (only small ciliate taxa $<35 \mu \mathrm{m})$ or the whole sedimentation chamber 
was analysed (larger ciliate taxa $>35 \mu \mathrm{m}$ and rotifers). Heterotrophic nanoflagellates (HNF) and bacteria were fixed in concentrated formol solution ( $2 \%$ final solution) with $10 \mathrm{~mL}$ sample volume per replicate. For cell counting with the epifluorescence microscope, $3 \mathrm{~mL}$ subsamples were filtered over $0.2 \mu \mathrm{m}$ pore-sized black nuclepore filters (CORNING; $25 \mathrm{~mm}$ diameter), which were subsequently stained with 4,6-diamidino-2-phenylindol (DAPI). A minimum of 100 (400x magnification) and 400 cells per filter (1000x magnification) were counted for HNF and bacteria, respectively.

Phytoplankton, ciliate and rotifer biovolumes were calculated using taxon-specific body volumes as previously established for Lake Constance (Kümmerlin and Bürgi, 1989; Müller et al., 1991; Pauli, 1989). The mean cell volume of $\mathrm{HNF}$ and bacteria used for biovolume calculation was 15.09 (Børsheim and Bratbak, 1987) and $0.036 \mu \mathrm{m}^{3}$ (Simon, 1987), respectively.

\section{Statistical analysis}

Differences in biovolumes between treatments and experiments for the individual plankton groups were analysed using two-way ANOVA (factor 1: Treatment; levels: E, C; factor 2: Experiment; levels: 1-3) and type II sum of squares. To ensure homogeneity of variance, data were $\log _{10}$-transformed prior to statistical analyses.

Taxon- (Supplementary Table SI) and group-specific clearance rates of $E$. gracilis were calculated from prey concentrations in $\mathrm{C}$ and $\mathrm{E}$ bottles at the end of the incubation (Rigler, 1971; Båmstedt et al., 2000), i.e. assuming exponential dynamics (i.e. growth or possibly declines due to microzooplankton grazing and/or bottle effects) of prey concentrations in the $\mathrm{C}$ bottles:

$$
F=\ln \frac{C}{E_{i}} * \frac{V}{t * n}
$$

where $F$ is the clearance rate $\left[\mathrm{mL}^{*} \operatorname{animal}^{-1} * \mathrm{~h}^{-1}\right], C$ is the geometric mean biovolume of each group in the control/no copepod treatments, $E_{i}$ is the biovolume of each group in replicate $i$ of treatment $E, V$ is the bottle volume $[\mathrm{mL}], t$ is the experimental duration $[\mathrm{h}]$ and in is the number of adult Eudiaptomus in replicate $i$ of treatment $E$ at the end of the experiments (for detailed explanation and derivation of this formula, see Supplementary text T1). This number ranged between 26 and 30 individuals, i.e. average mortality of Eudiaptomus during the experiment was low $(7.7 \%)$. For each experiment separately, differences between mean clearance rates of prey groups were examined using one-way mixed effects ANOVA. Here, replicates were used as a random factor in order to account for non-independence of clearance rates on the various prey groups within each replicate. Pairwise post-hoc comparisons were analysed using Tukey's HSD (R package multcomp, Hothorn et al., 2008). Evidently, clearance rate replicates calculated with mean control biovolumes cannot be considered independent (Jason Stockwell, personal communication). Moreover, control and grazer treatments were not paired. Thus, mixed effects ANOVA and post-hoc comparisons were not conducted using the clearance rates calculated from geometric mean control biovolumes, but using clearance rates for all possible combinations of control and grazer bottles (i.e. $4 !=24$ combinations of four grazer and four control bottles).

The analysis of size-specific grazing impacts was conducted using three independent approaches: (1) size-specific clearance rates were calculated for distinct size classes, which were formed by rounding $\log _{10}$ transformed body volume to the nearest integer: size class -1 : $0.04-0.3 \mu \mathrm{m}^{3}$ cell volume; size class $1: 4-15 \mu \mathrm{m}^{3}$; size class 2: $40-300 \mu \mathrm{m}^{3}$; size class 3: $350-2700 \mu \mathrm{m}^{3}$; size class 4: $3200-30000 \mu^{3}$; size class 5: 32000 $279000 \mu^{3}$; size class 6: $335000-443000 \mu^{3}$. (2) body volume distributions for control and Eudiaptomus treatments were calculated using kernel density plots with gaussian kernels and (3) weighted mean body volume $\left(\mathrm{BVM}_{w}\right)$ and weighted body volume variance $\left(\mathrm{BVV}_{w}\right)$ of phytoplankton, ciliates and rotifers were calculated as

$$
\begin{aligned}
\mathrm{BVM}_{w} & =\frac{\sum_{i=1}^{n} B_{i} * B V_{i}}{\sum_{i=1}^{n} B_{i}} \text { and } \\
\mathrm{BVV}_{w} & =\frac{\sum_{i=1}^{n} B_{i} * B V_{i}^{2}}{\sum_{i=1}^{n} B_{i}}-\mathrm{BVM}_{w}^{2}
\end{aligned}
$$

with $B$ and $B V$ as biovolume (body volume $*$ concentration) and $\log _{10}$ body volume of each taxon within the respective groups (Acevedo-Trejos et al., 2018). Differences in $\mathrm{BVM}_{w}$ and $\mathrm{BVV}_{w}$ between treatments and experiments were analysed using two-way ANOVA and type II sum of squares. All calculations were conducted using the packages car (Fox and Weisberg, 2018) and multcomp (Hothorn et al., 2008) with the statistical software R 3.5.0 (R Core Team, 2018).

\section{RESULTS}

A total of 55 phytoplankton, 44 ciliate and 11 rotifer taxa (including undefined ciliates and rotifers; Supporting Information Table SI) were identified. Overall and across all three experiments, Eudiaptomus gracilis decreased the biovolume of phytoplankton (average decrease across all three experiments: $25 \%$ ), ciliates $(67 \%)$ and rotifers 

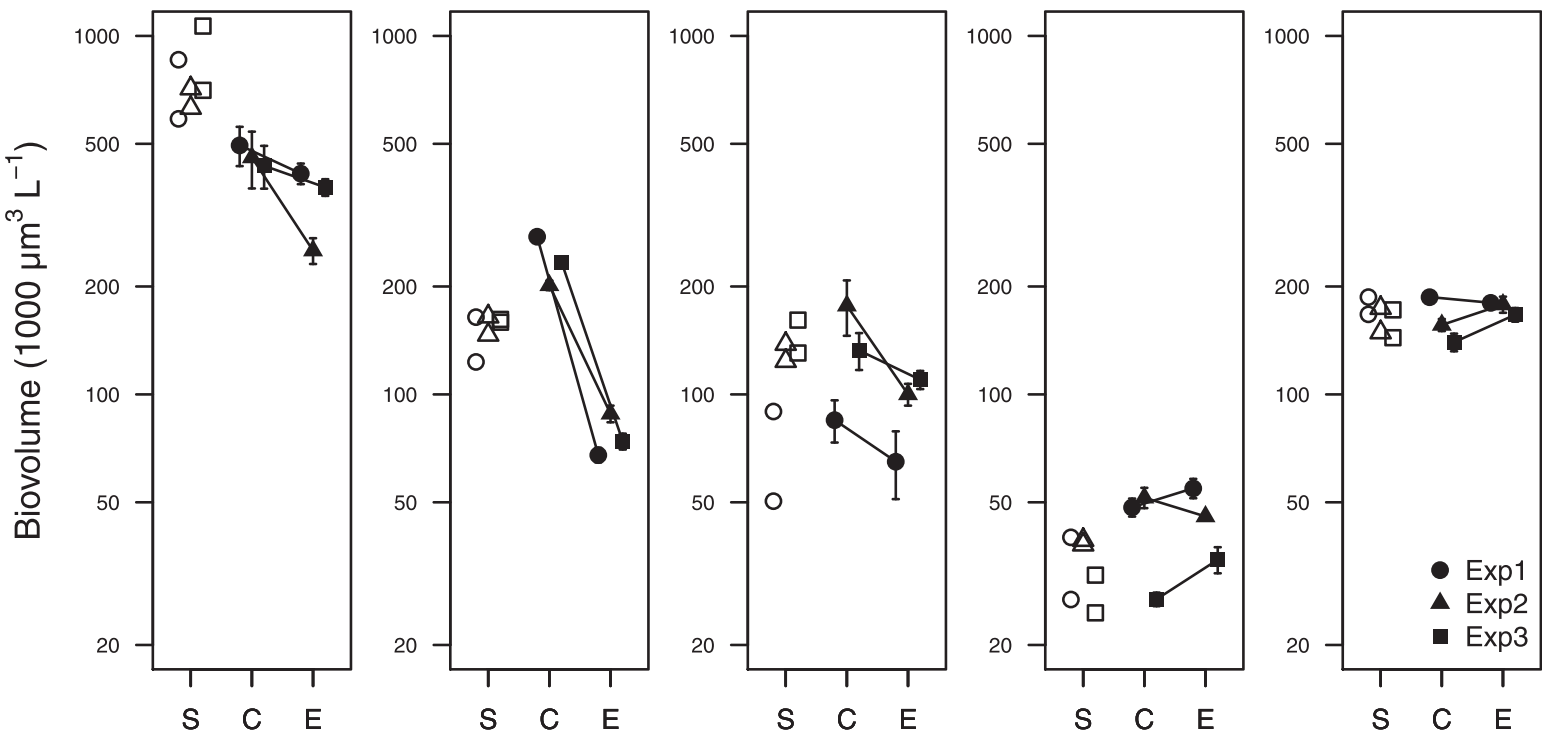

Fig. 1. Responses of biovolumes of to Eudiaptomus grazing: (a) phytoplankton, (b) ciliates, (c) rotifers, (d) HNF and (e) bacteria. S = starting point $(n=2) ; \mathrm{C}=$ control; $\mathrm{E}=$ copepod treatment $(n=4)$. Symbols indicate the different experiments (Circles: Experiment 1; triangles: Experiment 2 and squares: Experiment 3). Open symbols represent initial samples (S) at the starting point and filled symbols represent experimental samples $(\mathrm{C}+\mathrm{E})$ after $72 \mathrm{~h}$. Error bars indicate \pm one standard error of the mean.

(28\%). Whilst $E$. gracilis increased the biovolume of bacteria $(9 \%)$, it did not influence HNF biovolume (Fig. 1; Table I, significant main effects of treatment). Biovolumes significantly differed between experiments for ciliates, rotifers, HNF and bacteria (significant main effect of experiment). Yet, experiment effects differed between groups. For example, rotifers biovolumes were lowest in Experiment 1, whereas HNF biovolumes were lowest in Experiment 3.

The effect of E. gracilis on ciliate and HNF biovolume differed significantly between experiments. (Fig. 1; Table I, significant treatment $\times$ experiment interaction). For ciliates, this significant interaction term resulted from larger Eudiaptomus effects in Experiment 1 (75\% decline) compared to experiments 2 and 3 (56 and 68\% decline, respectively). Eudiaptomus decreased HNF biovolume in Experiment 2 (11\%), but increased HNF biovolume in experiments 1 and 3 (13 and 29\%, respectively). Compared to the in situ samples, phytoplankton biovolume was lower in both treatments whereas ciliate in situ biovolume was lower compared to the control but higher compared to the Eudiaptomus treatment (Fig. 1).

We found significant differences between clearance rates on plankton groups in all experiments and all permutations performed (all $P<0.05$ ). Clearance rates on ciliates were higher than those on other taxa in experiments 1 and 3 in all permutations (Fig. 2). In Experiment 2, all permutations revealed that clearance rates on phytoplankton, ciliates and rotifers were larger than those on bacteria (Fig. 2). Other differences between groups were not consistently observed across all permutations.

Size class-specific clearance rates were low up to size class 2 and high for all groups (i.e. phytoplankton and ciliates) in size classes 3 and 4, but were group-specific in size classes 5 and 6 . Ciliate clearance rates were also high in the latter two size groups whereas those for phytoplankton (size class 5, Ceratium hirundinella) and rotifers (size classes 5 and 6, various species) were low (Fig. 3).

As a consequence of the various size- and groupspecific clearance rates, Eudiaptomus grazing led to decreased biovolumes between $\sim 10^{3}$ and $10^{5} \mu \mathrm{m}^{3}$ (Fig. 4). This is mainly as a result of high clearance rates of abundant species, such as e.g. the algae Cryptomonas ovata, Gymnodinium helveticum and Stephanodiscus medius as well as the ciliates Histobalantium spp., Strobilidium lacustris and Pelagostrombidium spp. (Supplementary Table SI). The large biovolume declines in the $10^{3}$ and $10^{5} \mu \mathrm{m}^{3}$ size ranges resulted in the relative increases of biovolumes (between $10^{1}$ and $10^{3} \mu^{3}$ ), specifically in Ochromonas $s p$., Rhodomonas minuta and Rhodomonas minuta v. nannoplanctica.

Eudiaptomus grazing reduced phytoplankton $\mathrm{BVM}_{w}$, increased phytoplankton $\mathrm{BVV}_{w}$, but had no effect on rotifer $\mathrm{BVM}_{w}$ and $\mathrm{BVV}_{w}$ (Fig. 5, Table I). For ciliates, effects of Eudiaptomus on $\mathrm{BVM}_{w}$ and $\mathrm{BVV}_{w}$ were experiment-specific: In Experiment 1, Eudiaptomus grazing decreased $\mathrm{BVM}_{w}$ and increased $\mathrm{BVV}_{w}$, whereas 
Table I: Analysis of variance (type II ANOVA) of the effects of treatment, experiment (Exp) and the interaction between treatment and experiment (treatment $\times$ exp) on biovolumes, weighted mean body volume $\left(B V M_{w}\right)$ and weighted body volume variance $\left(B V V_{w}\right)$ of the five plankton groups.

\begin{tabular}{|c|c|c|c|c|c|c|c|}
\hline \multirow[b]{2}{*}{ Factor } & \multirow[b]{2}{*}{$d f$} & \multicolumn{2}{|c|}{ Biovolume } & \multicolumn{2}{|l|}{$\mathrm{BVM}_{w}$} & \multicolumn{2}{|l|}{$\mathrm{BVV}_{w}$} \\
\hline & & F value & $P$ value & $F$ value & $P$ value & $F$ value & $P$ value \\
\hline \multicolumn{8}{|c|}{ Phytoplankton } \\
\hline Treatment & 1,18 & 7.5130 & $0.0134 *$ & 7.1757 & $0.0153^{*}$ & 7.2572 & $0.0148 *$ \\
\hline Exp & 2,18 & 1.8742 & 0.1822 & 3.0921 & 0.0701 & 23.6224 & $<0.001^{* * *}$ \\
\hline $\begin{array}{l}\text { Treatment } \\
\times \text { Exp } \\
\text { Ciliates }\end{array}$ & 2,18 & 1.2191 & 0.3188 & 0.1592 & 0.8540 & 0.5652 & 0.5780 \\
\hline Treatment & 1,18 & 1751.944 & $<0.001^{* * *}$ & 0.0140 & 0.9072 & 1.1158 & 0.3048 \\
\hline Exp & 2,18 & 16.863 & $<0.001^{* * *}$ & 35.4563 & $<0.001^{* * *}$ & 35.5919 & $<0.001^{* * *}$ \\
\hline $\begin{array}{l}\text { Treatment } \\
\times \text { Exp } \\
\text { Rotifers }\end{array}$ & 2,18 & 50.848 & $<0.001^{* * *}$ & 3.5835 & $0.0490^{*}$ & 5.4844 & $0.0138^{*}$ \\
\hline Treatment & 1,18 & 8.7624 & $0.0084^{* *}$ & 0.1224 & 0.7305 & 0.0248 & 0.8767 \\
\hline Exp & 2,18 & 7.9682 & $0.0033^{* *}$ & 3.6808 & $0.0457^{*}$ & 16.0122 & $<0.001^{* * *}$ \\
\hline $\begin{array}{l}\text { Treatment } \\
\times \text { Exp } \\
H N F\end{array}$ & 2,18 & 1.8979 & 0.1787 & 0.3101 & 0.7372 & 0.4919 & 0.6195 \\
\hline Treatment & 1,18 & 1.6530 & 0.2149 & & & & \\
\hline Exp & 2,18 & 37.6131 & $<0.001^{* * *}$ & & & & \\
\hline $\begin{array}{l}\text { Treatment } \\
\times \text { Exp } \\
\text { Bacteria }\end{array}$ & 2,18 & 4.1287 & $0.0334^{*}$ & & & & \\
\hline Treatment & 1,18 & 5.9285 & $0.0255^{*}$ & & & & \\
\hline Exp & 2,18 & 9.1138 & $0.0018^{* *}$ & & & & \\
\hline $\begin{array}{l}\text { Treatment } \\
\times \text { Exp }\end{array}$ & 2,18 & 3.2978 & 0.0602 & & & & \\
\hline
\end{tabular}

Significance codes: ${ }^{\prime * * * \prime}:<0.001,{ }^{\prime * * \prime}:<0.01,{ }^{\prime * \prime}:<0.05,{ }^{\prime \prime},:<0.1$, Since variability of body volumes in HNF and bacteria was not measured, no tests of $B V M_{w}$ and $B V V_{w}$ were performed.

in the other two experiments (Experiments 2 and 3), there were only weak effects on ciliate $\mathrm{BVM}_{w}$ and $\mathrm{BVV}_{w}$. Decreased ciliate $\mathrm{BVM}_{w}$ and increased $\mathrm{BVV}_{w}$ in Experiment 1 (Fig. 5b and e) resulted from lower clearance rates in size class 3 (Fig. 3).

\section{DISGUSSION}

Our experiments revealed strong effects of a calanoid copepod species on the taxonomic and size structure of a plankton community. Eudiaptomus gracilis grazing resulted in significant declines of phytoplankton, ciliate and rotifer biovolumes. However, our first hypothesis assuming sizerelated differences between clearance rates for all prey groups was only partially confirmed. This is mainly due to relatively higher clearance rates on ciliates than those on phytoplankton. Yet, clearance rates on rotifers were lower than those on ciliates and similar to those on phytoplankton. Regarding phytoplankton, our results (mean clearance rate: $0.19 \mathrm{~mL}$ animal ${ }^{-1} \mathrm{~h}^{-1}$ ) are consistent with Zánkai and Ponyi (Zánkai and Ponyi, 1986) and Gulati (Gulati, 1978) who report average clearance rates of 0.12-0.24 mL animal ${ }^{-1} \mathrm{~h}^{-1}$ for female E. gracilis, respec- tively. Higher clearance rates on ciliates relative to phytoplankton and of similar magnitude to our findings were also reported for other calanoid copepods, including for the closely related Eudiaptomus graciloides in mesotrophic Lake Großer Vätersee $\left(0.22 \mathrm{~mL}\right.$ animal ${ }^{-1} \mathrm{~h}^{-1}$ for Chl a; $1.24 \mathrm{~mL}$ animal ${ }^{-1} \mathrm{~h}^{-1}$ for ciliates; Adrian and SchneiderOlt, 1999). Likewise, ciliates contributed $96.9 \%$ of total carbon ingested by the copepod Epischura baikalensis in oligotrophic Lake Baikal (Moore et al., 2019). Overall, studies that explore the effects of smaller-sized calanoids on rotifers are rather rare. Stoecker and Egloff (1987) showed that the marine calanoid Acartia tonsa strongly preferred ciliates and rotifers over phytoplankton, but we are not aware of any study that compares feeding on rotifers versus ciliates of freshwater calanoids. Williamson and Butler (Williamson and Butler, 1986) showed that the small calanoid Diaptomus pallidus strongly prefers several rotifer species over phytoplankton when offered both food types at similar concentrations. In contrast, Eudiaptomus gracilis was shown to feed on rotifers but feeding on rotifers declined strongly when the green alga Chlamydomonas geitleri was offered simultaneously at $0.08 \mathrm{mmol}$ $\mathrm{C} \mathrm{L} \mathrm{L}^{-1}$ (Sorf and Brandl, 2012). We show that in a prey community with natural concentrations of phytoplankton 
(a) $\operatorname{Exp} 1$

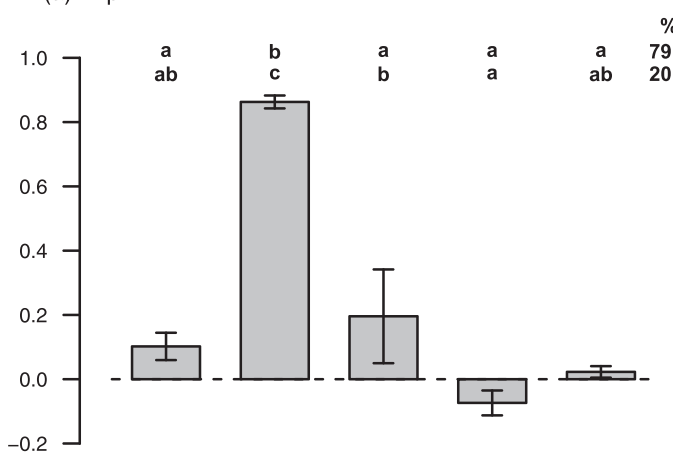

(b) $\operatorname{Exp} 2$

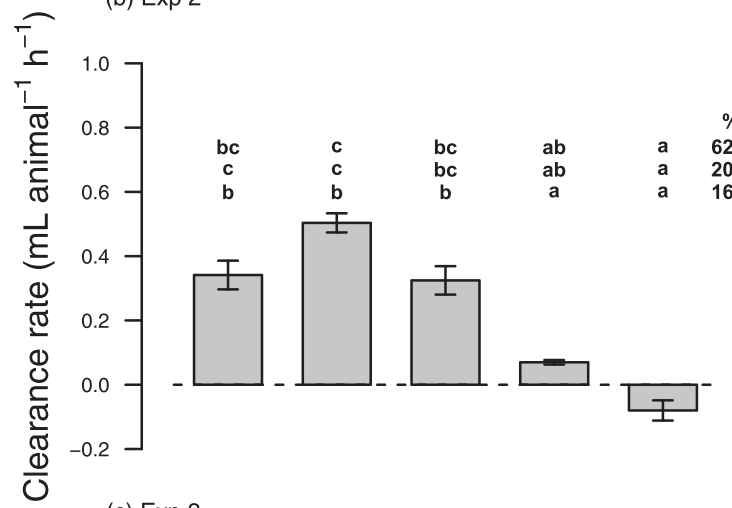

(c) $\operatorname{Exp} 3$

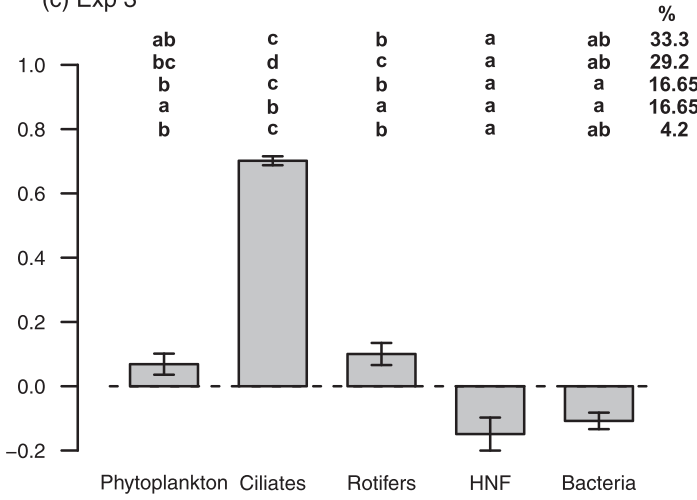

Fig. 2. Mean clearance rates of Eudiaptomus gracilis for the investigated plankton groups in the three experiments. Error bars indicate \pm one standard error of the mean and were calculated based on clearance rates estimated using the geometric mean control biovolumes. Letters represent the results from Tukey's post-hoc test calculated for all permutations of control and grazer bottles within the three experiments. Clearance rates of plankton groups differed significantly from other groups when they are flagged with a different letter $(P<0.05)$. As not all permutations revealed the same differences between clearance rates of plankton groups, all permutations results are shown for each experiment and their relative frequency is given. Note that the mean clearance rate calculated across all permutations is identical to the mean clearance rate calculated using the geometric mean of control biovolumes.

and rotifers, clearance rates on both groups were of similar magnitude. However, Eudiaptomus clearance rates for ciliates were considerably higher than those for rotifers in

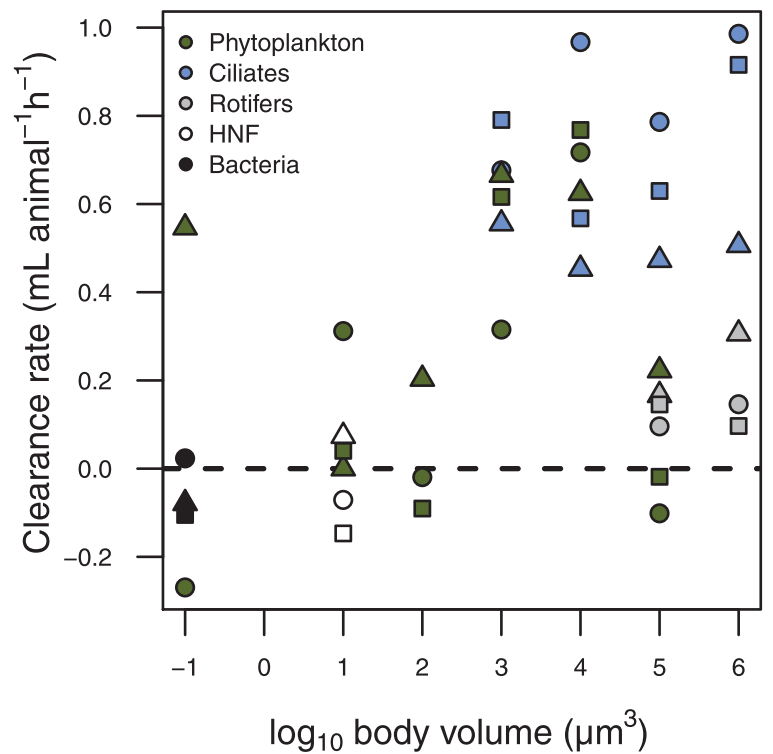

Fig. 3. Taxon- and size-specific clearance rates of Eudiaptomus gracilis. Clearance rates were calculated after aggregating body volumes into size classes $\left(\log _{10}\right.$ transformed biovolumes rounded to the nearest integer). See Figure 1 for explanation of the different symbols.

two out of the three experiments. Obviously, no predators of Eudiaptomus were included in our experiments. It is presently unclear whether predator presence might have altered foraging behaviour and thus clearance rates of the copepod.

Any ranking of clearance rates regarding different prey groups in our experiments needs to take indirect grazing effects, i.e. cascading trophic interactions, into account. Reduction of herbivorous ciliates and rotifers by Eudiaptomus gracilis will relieve phytoplankton from grazing pressure. In fact, it is likely that observed clearance rates on phytoplankton might underestimate true phytoplankton clearance rates of E. gracilis. The comparison of the in situ prey biovolumes $(\mathrm{S})$ with the control treatment $(\mathrm{C})$ also supports the presence of cascading interactions from $E$. gracilis via ciliates to phytoplankton: in situ phytoplankton biovolume exceeded control phytoplankton biovolume, whereas the opposite was the case for ciliates. This suggests that exclusion of $E$. gracilis and other crustacean zooplankton from the control caused biovolume increases of ciliates and declines of phytoplankton (Fig. 1). The general comparison with the in situ samples suggests that ciliate biovolume in Lake Constance is indeed top-down controlled, and that ciliates can control phytoplankton dynamics during specific time periods in this lake. The latter has also been suggested by steady-state carbon flow models (Gaedke and Straile, 1994) and simulation studies (Kerimoglu et al., 2013). 
(a) Exp 1

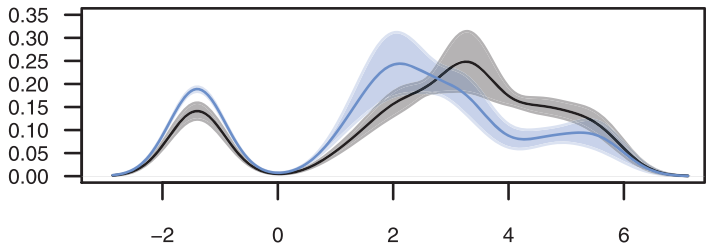

(b) Exp 2

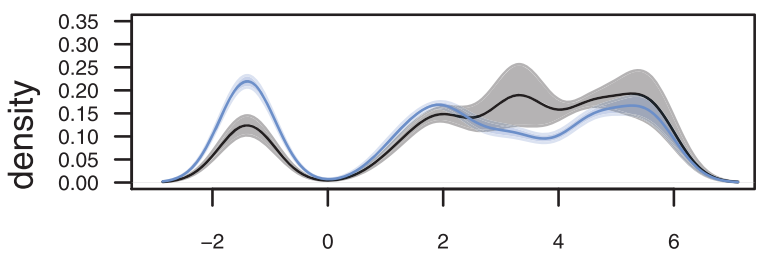

(c) $\operatorname{Exp} 3$

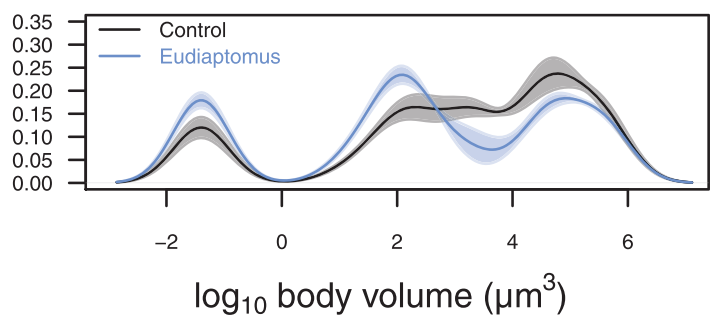

Fig. 4. Density distribution across the prey size spectrum in the contro and Eudiaptomus treatments. Lines represent the mean cell density across the four replicates; polygons depict the area within \pm one standard error of the mean.

Our results do support the second hypothesis whereby an overall increase of bacteria biovolume was observable, presumably due to cascading interactions. In addition, bacterial growth might be also stimulated by Eudiaptomus defecation and sloppy feeding (Hygum et al., 1997), although bacterial dynamics in pelagic systems have often been shown to be controlled by protozoan grazing (e.g. Bloem and Bär-Gilissen, 1989; Domaizon et al., 2003). Hence, we consider it more likely that the increase of bacteria in the Eudiaptomus treatment was caused by the observed reduction of bacterivorous ciliates (e.g. Coleps spp., Cyclidium spp.) and/or mixotrophic phytoplankton (e.g. Gymnodinium helveticum, G. lantzschii), whereas HNF which have been considered being important bacterivores in Lake Constance (Weisse and Müller, 1998; Cleven and Weisse, 2001) were not affected by Eudiaptomus gracilis. To our knowledge, this is the first time that cascading effects of $E$. gracilis on bacteria have been reported. Hence, dominance of calanoids in oligotrophic lakes might via suppression of bacterivores partially contribute to the observed high bacteria-phytoplankton biomass ratios observed in these systems (Simon et al., 1992).
Contrary to our third prediction, directional selection, i.e. a reduction of mean body sizes, was not observed in all groups, but solely in phytoplankton and in one additional experiment for ciliates. For rotifers, the size range present in the experiments was presumably too small and hence Eudiaptomus gracilis did not lead to altered rotifer community composition based on size. The variation in clearance rates for several intermediate size classes of prey and taxonomic groups indicates that $E$. gracilis does not select its prey based solely on prey size or biovolume. There are several additional factors that may well influence copepod prey selection. These include prey motility (which triggers the ambush feeding of copepods and increases encounter rates with prey; Jonsson et al., 2004), texture (aloricate ciliates such as Didinium spp. and Strobilidium spp. and aloricate rotifers, e.g. Polyarthra dolichoptera and Synchaeta spp., are preferred over those with a lorica; Brandl, 2005), presence/absence of escape responses (e.g. escape jumps of Askenasia spp. and Strobilidium spp.; Tamar, 1979; spines of Keratella cochlearis; Williamson, 1987), and even chemical properties of food items (Friedman and Strickler, 1975; DeMott, 1988).

Ciliates experienced uniformly high clearance rates across their size range providing no evidence for size selection in two of the three experiments. In all cases when directional selection was observed, there was also evidence for disruptive selection, i.e. an increase of size variance. Hence, contrary to our third hypothesis, Eudiaptomus grazing did not result in an association of directional and stabilising selection, but in an association of directional and disruptive selection. For phytoplankton, this two-fold selective signature most likely is a combined effect of both $E$. gracilis (non-) feeding and reduced ciliate feeding. The decrease of phytoplankton $\mathrm{BVM}_{w}$ is likely due to reduced biovolumes of phytoplankton species in the $10^{3}-$ $10^{5} \mu \mathrm{m}^{3}$ size range coupled to the lack of phytoplankton reduction in the $10^{1}-10^{3} \mu \mathrm{m}^{3}$ size range. The increase of phytoplankton $\mathrm{BVV}_{w}$ is due to the relative increase of biovolume at the lower phytoplankton size range was accompanied by a relative increase of biovolume in the higher phytoplankton size range as the largest phytoplankton species, Ceratium hirundinella, was also not suppressed in the Eudiaptomus treatment. The closely related species, Ceratium furcoides, is defined as nutritionally poor or inadequate for egg development in E. gracilis (Santer, 1996). Directional selection of ciliates in Experiment 1 was mostly due to lower clearance rates and consequently higher biovolumes of small ciliates such as Balanion planctonicum, which shifted $\mathrm{BVM}_{w}$ to a lower value. Middlesized ciliates such as Coleps spp. and Pelagohalteria viridis did decline in the Eudiaptomus treatment comparatively stronger than the largest ciliates, and the $\mathrm{BVV}_{w}$ also increased. 
(a) Phytoplankton

(b) Ciliates

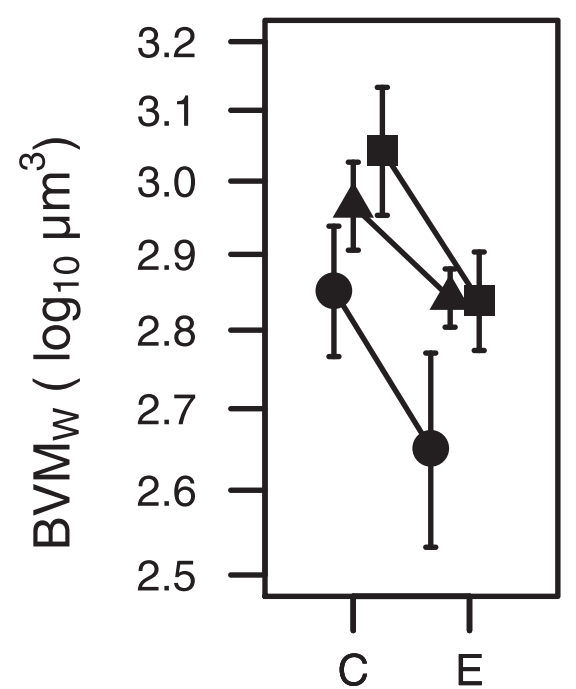

(d)

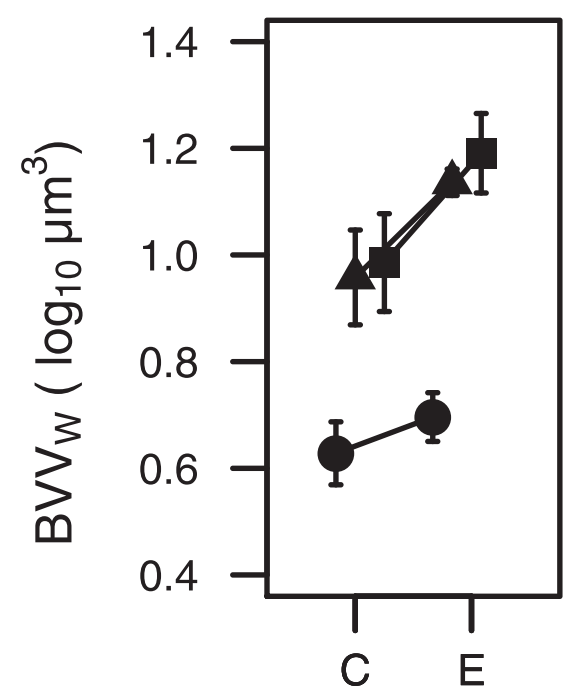

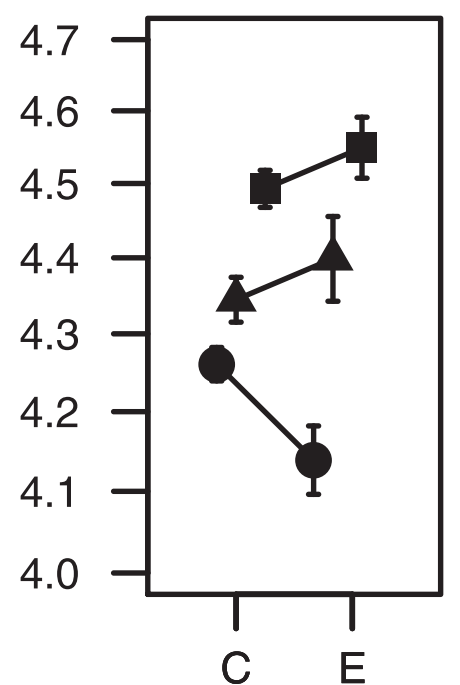

(e)

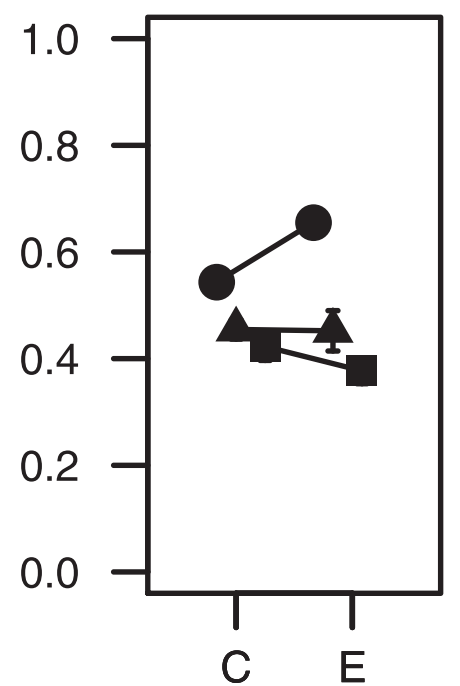

(c) Rotifers

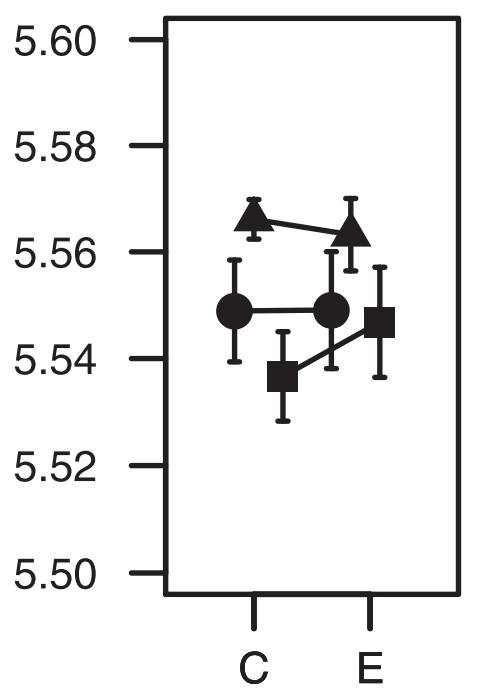

(f)

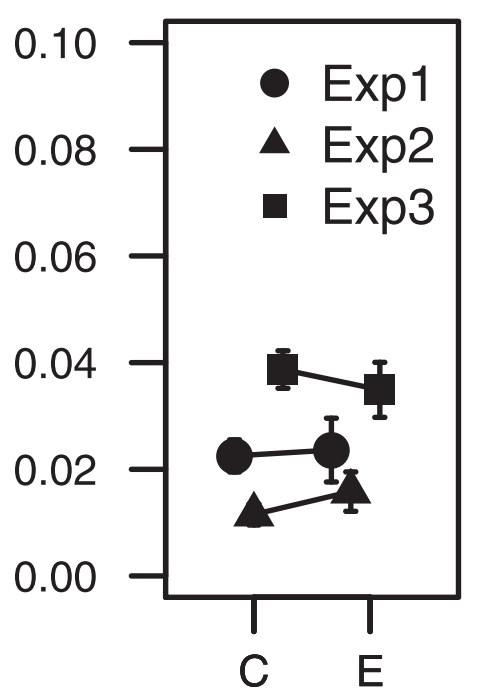

Fig. 5. Weighted mean $\left(\mathrm{BVM}_{w}\right)$ and weighted variance $\left(\mathrm{BVV}_{w}\right)$ of $\log _{10}$ transformed body volumes in the control $(\mathrm{C})$ and the copepod treatment $(\mathrm{E})$ in each of the three experiments. $(\mathbf{a}, \mathbf{d})$ phytoplankton; $(\mathbf{b}, \mathbf{e})$ ciliates and $(\mathbf{c}, \mathbf{f})$ rotifers. Error bars indicate \pm one standard error of the mean.

Finally, we could reject our fourth hypothesis for phytoplankton as we found decreasing biovolume and $\mathrm{BVM}_{\mathrm{W}}$ and increasing $\mathrm{BVV}_{w}$ in all experiments. For the biovolumes, $\mathrm{BVM}_{w}$, and $\mathrm{BVV}_{w}$ of other groups, we observed either significant experiment effects or significant treatment $\times$ experiment interactions (Table I). However, in case of ciliates and rotifers, Eudiaptomus grazing resulted in reduced biovolumes in all three experiments. The observed significant experiment $\times$ treatment interaction resulted from a different effect size of Eudiaptomus grazing (Fig. 1) and not from the presence or absence of an
Eudiaptomus effect. In contrast, for $\mathrm{HNF}$ and bacteria, the treatment effects seem to vary qualitatively as well. However, the reason for this is not clear and more experiments would be required to resolve the causes of shortterm variability of experimental outcomes. Methodological differences between Experiment 3 versus Experiments 1 and 2 (100 versus $55 \mu \mathrm{m}$ mesh size; see methods) are unlikely to have caused the differences between experiments as, e.g. clearance rate differences between groups were rather similar in Experiments 1 and 3, but differed from Experiment 2. In summary, we observed consistent 
treatment effects in regard to the biovolumes of the main prey items, phytoplankton, ciliates and rotifers across experiments. In contrast, effects on $\mathrm{HNF}$ and bacteria as well as effects on group size structures (except on phytoplankton $\mathrm{BVM}_{w}$ ) were less consistent and showed significant temporal variability even within a short time period of 3 weeks.

\section{GONGLUSION}

Applying an in situ incubation approach in large and deep Lake Constance, we obtained strong evidence that grazing of the calanoid copepod Eudiaptomus gracilis can influence the taxonomic and size structure of the lower plankton food web. Hence, Eudiaptomus grazing has the potential to change, e.g. trophic transfer efficiency (Carrick et al., 1991) and nutrient recycling (Sailley et al., 2014) in pelagic food webs. Largest clearance rates were observed for ciliates, which most likely resulted in cascading effects, i.e. an increase of bacteria biovolume and a reduced decline of smaller-sized phytoplankton. Large clearance rates of ciliates probably also contributed to the observed directional and disruptive selection on phytoplankton size. Thus, changes in phytoplankton size structure may not be understood without considering cascading interactions and the omnivory of consumers.

It is not yet clear if the observed co-occurrence of directional and disruptive selection in natural phytoplankton communities is season-specific and typical for $E$. gracilis, and whether such a coupling of selection modes exists also for grazers which are less omnivorous and may tend either to a phytoplankton diet (e.g. daphnids) or to a more ciliate-based diet (e.g. cyclopoid copepods). This suggests that there is a need for experiments in which (a) the size response of prey plankton communities to consumers differing in their degree of omnivory, and (b) seasonal variability of the selection pressure on plankton size structure is examined. Finally, controlled laboratory experiments using multiple trophic levels are needed as experiments using only trait variability at two trophic levels, e.g. phytoplankton and herbivores, will most likely only reveal an incomplete picture of selective factors affecting algal communities. Irrespective of any future work, our study suggests that the quantification of higherlevel processes sensu Vellend (2016) might represent a promising tool to analyse predation effects on plankton communities possibly resulting in improved comparability of predator effects within and between ecosystems.

\section{AGKNOWLEDGEMENTS}

We thank Eva Lievens, Jason Stockwell and two anonymous reviewers for comments, which greatly improved the content of the manuscript.

\section{FUNDING}

This study was funded by the Deutsche Forschungsgemeinschaft (DFG, German Research Foundation, 298726046/GRK2272).

\section{REFERENGES}

Acevedo-Trejos, E., Marañón, E. and Merico, A. (2018) Phytoplankton size diversity and ecosystem function relationships across oceanic regions. Proc. R. Soc. B Biol. Sci., 285, 20180621.

Adrian, R. and Schneider-Olt, B. (1999) Top-down effects of crustacean zooplankton on pelagic microorganisms in a mesotrophic lake. $\mathcal{f}$. Plankton Res., 11, 2175-2190.

Anneville, O., Molinero, J. C., Souissi, S., Balvay, G. and Gerdeaux, D. (2007) Long-term changes in the copepod community of Lake Geneva. F. Plankton Res., 29, i49-i59.

Arhonditsis, G.B., Shimoda, Y. and Kelly, N.E. (2018) Allometric Theory: Extrapolations from Individuals to Ecosystems, 2nd edn. Elsevier Inc.

Båmstedt, U., Gifford, D. J., Irigoien, X., Atkinson, A. and Roman, M. (2000) Feeding. In Harris, R. P., Wiebe, P. H., Lenz, J., Skjoldal, H. R. and Huntley, M. (eds.), ICES Zooplankton Methodology Manual, Academic Press, San Diego, pp. 297-398.

Barbiero, R. P., Lesht, B. M. and Warren, G. J. (2012) Convergence of trophic state and the lower food web in lakes Huron, Michigan and superior. 7. Great Lakes Res., 38, 368-380.

Barbiero, R. P., Lesht, B. M. and Warren, G. J. (2014) Recent changes in the offshore crustacean zooplankton community of Lake Ontario. 7. Great Lakes Res., 40, 898-910.

Bloem, J. and Bär-Gilissen, M. B. (1989) Bacterial activity and protozoan grazing potential in a stratified lake. Limnol. Oceanogr., 34, 297-309.

Børsheim, K. Y. and Bratbak, G. (1987) Cell volume to cell carbon conversion factors for a bacterivorous Monas sp. enriched from seawater. Mar. Ecol. Prog. Ser., 36, 171-175.

Brandl, Z. (2005) Freshwater copepods and rotifers: predators and their prey. Hydrobiologia, 546, 475-489.

Brose, U., Jonsson, T., Berlow, E. L., Warren, P., Banasek-Richter, C., Bersier, L. F. et al. (2006) Consumer-resource body-size relationships in natural food webs. Ecology, 87, 2411-2417.

Bunnell, D. B., Barbiero, R. P., Ludsin, S. A., Madenjian, C. P., Warren, G. J., Dolan, D. M. et al. (2014) Changing ecosystem dynamics in the Laurentian Great Lakes: bottom-up and top-down regulation. Bioscience, 64, 26-39.

Burns, C. W. and Gilbert, J. J. (1993) Predation on ciliates by freshwater calanoid copepods: rates of predation and relative vulnerabilities of prey. Freshw. Biol., 30, 377-393. 
Burns, C. W. and Schallenberg, M. (2001) Calanoid copepods versus cladocerans: consumer effects on protozoa in lakes of different trophic status. Limnol. Oceanogr., 46, 1558-1565.

Burns, C. W. and Schallenberg, M. (1998) Impacts of nutrients and zooplankton on the microbial food web of an ultra-oligiotrophic lake. 7. Plankton Res., 20, 1501-1525.

Burns, C. W. and Schallenberg, M. (1996) Relative impacts of copepods, cladocerans and nutrients on the microbial food web of a mesotrophic lake. F. Plankton Res., 18, 683-714.

Carrick, H. J., Fahnenstiel, G. L., Stoermer, E. F. and Wetzel, R. G. (1991) The importance of zooplankton-protozoan trophic couplings in Lake Michigan. Limnol. Oceanogr., 36, 1335-1345.

Cleven, E. J. and Weisse, T. (2001) Seasonal succession and taxonspecific bacterial grazing rates of heterotrophic nanoflagellates in Lake Constance. Aquat. Microb. Ecol., 23, 147-161.

Coutinho, R. M., Klauschies, T. and Gaedke, U. (2016) Bimodal trait distributions with large variances question the reliability of trait-based aggregate models. Theor. Ecol., 9, 389-408.

DeMott, W. R. (1988) Discrimination between algae and artificial particles by freshwater and marine copepods. Limnol. Oceanogr., 33, 397-408.

DeMott, W. R. (1989) The role of competition in zooplankton succession. In Sommer, U. (ed.), Plankton Ecology: Succession in Plankton Communities, Springer, Berlin, pp. 195-252.

Dhanker, R., Kumar, R. and Hwang, J. S. (2012) Predation by Pseudodiaptomus annandalei (Copepoda: Calanoida) on rotifer prey: size selection, egg predation and effect of algal diet. 7. Exp. Mar. Bio. Ecol., 414-415, 44-53.

Domaizon, I., Viboud, S. and Fontvieille, D. (2003) Taxon-specific and seasonal variations in flagellates grazing on heterotrophic bacteria in the oligotrophic Lake Annecy - importance of mixotrophy. FEMS Microbiol. Ecol., 46, 317-329.

Van Donk, E., Hessen, D. O., Verschoor, A. M. and Gulati, R. D. (2008) Re-oligotrophication by phosphorus reduction and effects on seston quality in lakes. Limnologica, 38, 189-202.

Doubek, J. P. and Lehman, J. T. (2014) Historical trophic position of Limnocalanus macrurus in Lake Michigan. 7. Great Lakes Res., 40, 1027-1032.

Emmerson, M. C. and Raffaelli, D. (2004) Predator-prey body size, interaction strength and the stability of a real food web. F. Anim. Ecol., 73, 399-409.

Fessenden, L. and Cowles, T. J. (1994) Copepod predation on phagotrophic ciliates in Oregon coastal waters. Mar. Ecol. Prog. Ser., 107, 103-111.

Folke, C., Carpenter, S., Walker, B., Scheffer, M., Elmqvist, T., Gunderson, L. and Holling, C. S. (2004) Regime shifts, resilience, and biodiversity in ecosystem management. Anпu. Rev. Ecol. Evol. Syst., 35, 557-581.

Fox, J. and Weisberg, S. (2018) An R Companion to Applied Regression, 2nd edn, Sage Publications, Thousand Oaks, CA.

Friedman, M. M. and Strickler, J. R. (1975) Chemoreceptors and feeding in calanoid copepods (Arthropoda: Crustacea). Proc. Natl. Acad. Sci., 72, 4185-4188.

Gaedke, U. and Straile, D. (1994) Seasonal changes of the quantitative importance of protozoans in a large lake. An ecosystem approach using mass-balanced carbon flow diagrams. Mar. Microb. Food Webs, 8, 163-188.
Gianuca, A. T., Pantel, J. H. and De Meester, L. (2016) Disentangling the effect of body size and phylogenetic distances on zooplankton topdown control of algae. Proc. R. Soc. B Biol. Sci., 283,

Gliwicz, Z. M. and Pijanowska, J. (1989) The role of predation on zooplankton succession. In Sommer, U. (ed), Plankton Ecology, Springer, Berlin Heidelberg, pp. 253-296.

Gulati, R. D. (1978) The ecology of common planktonic crustacea of the freshwaters in the Netherlands. Hydrobiologia, 59, 101-112.

Hansen, B. W., Bjørnsen, P. K. and Hansen, P. J. (1994) The size ratio between planktonic predators and their prey. Limnol. Oceanogr., 39, 395-403.

Hansen, P. J., Bjørnsen, P. K. and Hansen, B. W. (1997) Zooplankton grazing and growth: scaling within the $2-2000 \mu \mathrm{m}$ body size range. Limnol. Oceanogr., 42, 687-704.

Hildrew, A. G., Raffaelli, D. and Edmonds-Brown, R. (2007) Body Size: The Structure and Function of Aquatic Ecosystems, Cambridge University Press, Cambridge.

Horn, W. (1985a) Investigations into the food selectivity of the Planktic crustaceans Daphnia hyalina, Eudiaptomus gracilis and Cyclops vicinus. Int. Rev. der gesamten Hydrobiol., 70, 603-612.

Horn, W. (1985b) Results regarding the food of the Planktic crustaceans Daphnia hyalina and Eudiaptomus gracilis. Int. Rev. der gesamten Hydrobiol., 70, 703-709.

Hothorn, T., Bretz, F. and Westfall, P. (2008) Simultaneous inference in general parametric models. Biometrical f., 50, 346-363.

Hygum, B. H., Petersen, J. W. and Søndergaard, M. (1997) Dissolved organic carbon released by zooplankton grazing activity - a highquality substrate pool for bacteria. 7. Plankton Res., 19, 97-111.

Jeppesen, E., Jensen, J. P. and Søndergaard, M. (2002) Response of phytoplankton, zooplankton, and fish to re-oligotrophication: an 11 year study of 23 Danish lakes. Aquat. Ecosyst. Heal. Manag., 5, 31-43.

Jeppesen, E., Søndergaard, M., Jensen, J. P., Havens, K. E., Anneville, O., Carvalho, L. et al. (2005) Lake responses to reduced nutrient loading - an analysis of contemporary long-term data from 35 case studies. Freshw. Biol., 50, 1747-1771.

Jochimsen, M. C., Kümmerlin, R. and Straile, D. (2013) Compensatory dynamics and the stability of phytoplankton biomass during four decades of eutrophication and oligotrophication. Ecol. Lett., 16, 81-99.

Jonsson, P. R., Johansson, M. and Pierce, R. W. (2004) Attachment to suspended particles may improve foraging and reduce predation risk for tintinnid ciliates. Limnol. Oceanogr., 49, 1907-1914.

Kerimoglu, O., Straile, D. and Peeters, F. (2013) Seasonal, inter-annual and long term variation in top-down versus bottom-up regulation of primary production. Oikos, 122, 223-234.

Kümmerlin, R. and Bürgi, H. R. (1989) Die langjährige Entwicklung des Phytoplanktons im Bodensee (1961-1986). Berichte der Int. Gewässerschutzkommission für den Bodensee, 39, 1-175.

Litchman, E., Klausmeier, C. A., Schofield, O. M. and Falkowski, P. G. (2007) The role of functional traits and trade-offs in structuring phytoplankton communities: scaling from cellular to ecosystem level. Ecol. Lett., 10, 1170-1181.

Moore, M. V., Silow, E. A., De Stasio Jr, B. T. and Huizenga, K. N. (2019) Trophic coupling of the microbial and the classical food web in Lake Baikal, Siberia. Freshw. Biol., 64, 138-151.

Muck, P. and Lampert, W. (1980) Feeding of freshwater filter-feeders at very low food concentrations: poor evidence for "threshold feeding" 
and "optimal foraging" in Daphnia longispina and Eudiaptomus gracilis. $\mathcal{F}$. Plankton Res., 2, 367-379.

Müller, H., Schöne, A., Pinto-Coelho, R. M., Schweizer, A. and Weisse, T. (1991) Seasonal succession of ciliates in Lake Constance. Microb. Ecol., 21, 119-138.

Pasternak, A. F. and Schnack-Schiel, S. B. (2001) Seasonal feeding patterns of the dominant Antarctic copepods Calanus propinquus and Calanoides acutus in the Weddell Sea. Polar Biol., 24, 771-784.

Pauli, H. R. (1989) A new method to estimate individual dry weights of rotifers. Hydrobiologia, 186, 355-361.

R Core Team (2018) R: a language and environment for statistical computing. R Foundation for Statistical Computing, Vienna, Austria. 2012. URL http://www.R-project.org.

Rigler, F. H. (1971) Feeding rates - Zooplankton. In Edmondson, W. T. and Winberg, W. W. (eds.), A Manual for the Assessment of Secondary Productivity in Freshwaters. IBP Handbook No. 17, Blackwell, Oxford, pp. 228-256.

Rudstam, L. G., Holeck, K. T., Bowen, K. L., Watkins, J. M., Weidel, B. C. and Luckey, F. J. (2015) Lake Ontario zooplankton in 2003 and 2008: community changes and vertical redistribution. Aquat. Ecosyst. Heal. Manag., 18, 43-62.

Sailley, S. F., Polimene, L., Mitra, A., Atkinson, A. and Allen, J. I. (2014) Impact of zooplankton food selectivity on plankton dynamics and nutrient cycling. F. Plankton Res., 37, 519-529.

Santer, B. (1996) Nutritional suitability of the dinoflagellate Ceratium furcoides for four copepod species. F. Plankton Res., 18, 323-333.

Scharf, F. S., Juanes, F. and Rountree, R. A. (2000) Predator size - prey size relationships of marine fish predators: interspecific variation and effects of ontogeny and body size on trophic-niche breadth. Mar. Ecol. Prog. Ser., 208, 229-248.

Schulze, P. C. and Folt, C. L. (1990) Food resources, survivorship, and reproduction of the omnivorous calanoid copepod Epischura lacustris. Ecology, 71, 2224-2240.

Seebens, H., Straile, D., Hoegg, R., Stich, H.-B. and Einsle, U. (2007) Population dynamics of a freshwater calanoid copepod: complex responses to changes in trophic status and climate variability. Limnol. Oceanogr., 52, $2364-2372$.

Simon, M. (1987) Biomass and production of small and large freeliving and attached bacteria in Lake Constance. Limnol. Oceanogr., 32 , 591-607.

Simon, M., Cho, B. G. and Azam, F. (1992) Significance of bacterial biomass in lakes and the ocean: comparison to phytoplankton biomass and biogeochemical implications. Mar. Ecol. Prog. Ser., 86, 103-110.

Sommer, U., Charalampous, E., Genitsaris, S. and Moustaka-Gouni, M. (2017) Benefits, costs and taxonomic distribution of marine phytoplankton body size. f. Plankton Res., 39, 494-508.

Sommer, U., Sommer, F., Feuchtmayr, H. and Hansen, T. (2004) The influence of Mesozooplankton on phytoplankton nutrient limitation: a Mesocosm study with Northeast Atlantic plankton. Protist, 155, 295-304.

Sommer, U., Sommer, F., Santer, B., Jamieson, C., Boersma, M., Becker, C. and Hansen, T. (2001) Complementary impact of copepods and cladocerans on phytoplankton. Ecol. Lett., 4, 545-550.

Søndergaard, M., Jeppesen, E., Mortensen, E., Dall, E., Kristensen, P. and Sortkjaer, O. (1990) Phytoplankton biomass reduction after planktivorous fish reduction in a shallow, eutrophic lake: a combined effect of reduced internal P-loading and increased zooplankton grazing. Hydrobiologia, 200/201, 229-240.
Šorf, M. and Brandl, Z. (2012) The rotifer contribution to the diet of Eudiaptomus gracilis (G. O. Sars, 1863) (Copepoda, Calanoida). Crustaceana, 85, 1421-1429.

Stich, H. B. (1989) Seasonal changes of diel vertical migrations of crustacean zooplankton in Lake Constance. Arch. für Hydrobiol. Suppl., 83, 355-405.

Stoecker, D. K. and Egloff, D. A. (1987) Predation by Acartia tonsa Dana on planktonic ciliates and rotifers. F. Exp. Mar. Bio. Ecol., 110, 53-68.

Straile, D. (2015) Zooplankton biomass dynamics in oligotrophic versus eutrophic conditions: a test of the PEG model. Freshw. Biol., 60, 174-183.

Straile, D. and Geller, W. (1998) Crustacean zooplankton in Lake Constance from 1920 to 1995: response to eutrophication and reoligotrophication. Arch. für Hydrobiol. Spec. Issues Adv. Limnol., 53, 255-274.

Tamar, H. (1979) The movements of jumping ciliates. Arch. für Protistenkd. Protozoen, Algen, Pilze, 122, 290-327.

Utermöhl, H. (1958) Zur Vervollkommnung der Quantitativen phytoplankton-Methodik. Mitt. Int. Ver. Theor. Angew. Limnol., 9, 1-39.

Vanderploeg, H. A. and Paffenhöfer, G. A. (1985) Modes of algal capture by the freshwater copepod Diaptomus and their relation to food-size selection. Limnol. Oceanogr., 30, 871-885.

Vellend, M. (2010) Conceptual synthesis in community ecology. Q. Rev. Biol., 85, 183-206.

Vellend, M. (2016) The Theory of Ecological Communities (MPB-57), Vol. 75, Princeton University Press.

Warren, G. J. (1985) Predaceous feeding habits of Limnocalanus macrurus. 7. Plankton Res., 7, 537-552.

Watkins, J. M., Weidel, B. C., Rudstam, L. G. and Holeck, K. T. (2015) Spatial extent and dissipation of the deep chlorophyll layer in Lake Ontario during the Lake Ontario lower foodweb assessment, 2003 and 2008. Aquat. Ecosyst. Heal. Manag., 18, 18-27.

Weisse, T. and Müller, H. (1998) Planktonic protozoa and the microbial food web in Lake Constance. Arch. für Hydrobiol. Spec. Issues Adv. Limnol., 53, 223-254.

Williamson, C. E. (1987) Predator-prey interactions between omnivorous diaptomid copepods and rotifers: the role of prey morphology and behavior. Limnol. Oceanogr., 32, 167-177.

Williamson, C. E. and Butler, N. M. (1986) Predation on rotifers by the suspension-feeding calanoid copepod Diaptomus pallidus. Limnol. Oceanogr., 31, 393-402.

Wong, C. K. and Chow-Fraser, P. (1985) The food of three large freshwater calanoid copepods: Limnocalanus macrurus Sars, Epischura lacustris Forbes, and Senecella calanoides Juday: With 3 figures in the text.. Internationale Vereinigung fur theoretische und angewandte Limnologie: Verhandlungen, 25, 3190-3194.

Yoshida, T., Gurung, T., Kagami, M. and Urabe, J. (2001) Contrasting effects of a cladoceran (Daphnia galeata) and a calanoid copepod (Eodiaptomus japonicus) on algal and microbial plankton in a Japanese Lake, Lake Biwa. Oecologia, 129, 602-610.

Zánkai, P. N. and Ponyi, J. E. (1986) Composition, density and feeding of crustacean zooplankton community in a shallow, temperate lake (Lake Balaton, Hungary). Hydrobiologia, 135, 131-147.

Zöllner, E., Hoppe, H.-G., Sommer, U. and Jürgens, K. (2009) Effect of zooplankton-mediated trophic cascades on marine microbial food web components (bacteria, nanoflagellates, ciliates). Limnol. Oceanogr., $\mathbf{5 4}, 262-275$. 